\title{
The bimodal character of stock distribution
}

\author{
A.G. Frank* \\ Regent College, University of Luton, P.O. Box 51201, \\ Musgrave 4062, Republic of South Africa \\ ashley frank@excite.com
}

Received October 2001

\begin{abstract}
The bimodal character of stocks is demonstrated when they are classified according to their style. Stocks are often assigned, on the basis of some valuation parameter, uniquely as either value or growth even though, over time, changes in a stock's-growth probability should trace the evolution of the corporate life cycle. This study is concerned with investigating the relationship of that probability to market cycles. Two hundred and eighty eight stocks from the ASEAN are tracked over an eight-year period. The percentages of those, on a monthly basis, that are in the top quintile of EPS growth, as well as the top quintile of major value (current) styles are calculated. Using multidimensional scaling, the study concludes that the degree of differentiation between growth and value rises as the market declines, and that styles are purer at the bottom than at the top of the market cycle.
\end{abstract}

*To whom all correspondence should be addressed.

\section{Introduction}

The majority of academic studies regarding investment styles have focused on long-run return differences between styles and the robustness of stock characteristics for explaining equity asset pricing in United States and international markets (cf., Banz, 1981; Rosenberg, Reid \& Lanstein, 1985; Fama \& French, 1992; Chan, Hamao \& Lakonishok, 1993; Jegadeesh \& Titman, 1993).

Although it is intuitively appealing to believe that bimodal stock characteristics are cyclical (i.e., there are more growth stocks during a bull period than a bear one) there are few academic studies that have attended solely to this question. Moreover analysis of cross-sectional data on stocks from the emerging markets have been few and far between. This is despite an understanding in the investment community that if these factors are taken into account, future rankings of performance might be predicted more accurately.

Within this context, the purpose of the current study is to determine whether the degree of overlap (the same counters being in opposing portfolios) is related to market direction when style portfolios of stocks from the Association of South East Asian Nations (ASEAN) are built.

\section{Academic foundations}

Malkiel (1993) contends that 'there appeared to be a considerable degree of predictability of stock returns on the basis of certain fundamental ratios and variables. Stock returns appeared to be predictable on the basis of such variables as initial dividend yields, market capitalization (size), price/earnings ratios and price/book value ratios. Of course return predictability need not imply inefficiency of equity markets. Time series tests of return predictability may reflect rational variation through time in expected returns ... The apparent robustness of certain predictable patterns has led to a view that our 1970s belief in the simplistic efficientmarkets constant-returns model was unwarranted'. Simply put, the predictable patterns indicate that trends (serial correlation) in the returns for segments of the market do exit. Thus the random-walk theory (Cootner, 1964) which states that future directions cannot be forecast on the basis of past action, is flawed.

This new way of thinking has been encouraged by the work of Fama and French (1992). Their research suggests that size and book to market value accounted for differences in return for segments of the market. Moreover they held that expected returns for different portfolio strategies could be estimated from historical returns of portfolios of similar size and book market values. As a whole Malkiel and Fama and French's work, speak quite clearly that segments of the market act differently over time and that pattern predictability exists.

Of course once this has been established the task of defining investment style occurs. Internationally trustees and fund managers have a number of alternatives open to defining investment style. The best known are probably the Standard and Poor / BARRA Growth and Value Indices, which were introduced in 1992. These indices are designed for a simple and intellectually appealing purpose. All stocks in the Standard and Poor 500 Index are ranked in order of their 
price to book value ratio ${ }^{1)}$. Stocks with the highest price to book ratios are assigned to the Growth Index until half of the Standard and Poor 500 capitalization has been assigned. The remainder form the Standard and Poor / BARRA Value Index. Because growth companies, by definition, have a share of capitalization greater than their book values, it requires fewer of them to make up half of the Standard and Poor's 500 total capitalization. The Standard and Poor / BARRA Growth Index has commonly contained between 180 and 200 companies. The remaining 300 to 320 form the Value Index (Sorensen \& Lazzara, 1995).

The simplicity of this approach brings with it both advantages and disadvantages. One particular disadvantage is the bimodal character of stock distribution. One variable, the price/book value ratio, assigns each stock uniquely to one of two categories - value or growth. If a numerical score of 1 is assigned to growth stocks and 0 to value stocks then the bimodal character is displayed. 'At some critical threshold as a stock's price/book ratio rises, the share will eventually make a quantum leap from zero to one' (Sorensen \& Lazzara, 1995; my emphasis).

This method of portfolio construction produces both expected and paradoxical results. Most predictably, the weighted average price/book ratio of the Growth Index is substantially above that of the Value Index ${ }^{2}$. The Growth Index also has a higher PE ratio, lower yield and higher average return on equity (ROE). These results are consistent with the impact of investors' expectations on pricing and the nature of growth stocks.

Ironically, because the Growth and Value Indices are engineered to have equal total capitalizations and because the Growth Index is lesser populated, the average capitalization of the companies in the Growth Index exceeds that of the Value index. At first thought this is not a logical result, as it runs counter to the wisdom expounded by Price's (1939) corporate life-cycle paradigm. Clearly, since it is easier to grow rapidly off a smaller base, it is rational to assume that a typical growth company is smaller than a typical value one.

Sergio and Sorensen (1992) argued that, in reality, style classifications cannot be strictly bimodal. Most stocks, they argued, would fall somewhere between the polar ends of pure growth and pure value. They preferred not to accept that a stock chosen at random had as equal a chance of being a value stock as a growth one. Going by the literature on growth stocks they figured that true growth would tend to be rare and that growth stocks should thus be in the minority. They made a conservative assumption that $25 \%$ of the stock universe was more growth-like than value-like ${ }^{3)}$.

\footnotetext{
${ }^{1)}$ Investors willingness to pay a higher multiple of book value is considered an indication of a stock's prospective growth rate.

${ }^{2)}$ At September 30, 1993, the price/book ratios of the Growth and Value Indices were 4,17 and 1,92, respectively.

${ }^{3)}$ Thus a randomly chosen stock is three times as likely to be a value stock than it is to be a growth stock.
}

It was their contention that, taking a realistic view of the world, only a minimum of stocks are pure growth or pure value, with the maximum falling into the middle range. At any point in time a stock's score can be thought of as the probability that it is a growth stock. Over time, changes in a stock's-growth probability trace the evolution of the corporate life-cycle. This study is concerned with investigating the relationship of that probability to market cycles. It is an important area to investigate as an increase in overlap blurs the distinction between value and growth approaches and decreases the purity of the investment play, while a decrease would conversely enhance style individuality. The hypothesis was framed as follows:

\section{$>$ The variation in overlap between growth and value} styles is aligned with market movement. The hypothesis suggests that the degree of overlap between those stocks defined as value and those defined as growth (the same counters are in the different portfolios) rises when the market rises and falls when the market falls.

\section{Research methdology}

Data from the Jardine Fleming Asean Strategy Database was extracted according to constraints of sample size and time frame. Relative return and risk was examined with perfect foresight (i.e., taking a long position in the higher performing portfolio and a short position in the lower returning one). Monthly data was used and where necessary, annual data was converted into a monthly format through a system of time weighting using trading days. Each style's action was documented over an eight-year period from the beginning of 1990 to the end of 1997.

\section{Universe and sample frame}

This study made use of key numbers on 288 stocks drawn from the $\mathrm{ASEAN}_{5}$ countries of Indonesia, Malaysia, Philippines, Singapore and Thailand. The stocks were selected such that each country was represented to at least $50 \%$ of its market capitalization and that the total percentage of regional market capitalization referred to, was at least $60 \%$.

Much has been written about the advantages and disadvantages of using capitalization weights ( $c f$. ., Ankrim, 1993; Ankrim \& Gardner, 1994; Gillies, 1990). The obvious attraction of this weighting system is that it reflects the aggregate market, thus because a regional view was sought, this approach to weighting was thought to be most effective. Umstead (1990) confirms that the capitalization-weighted aggregation of all individual securities (often called the market portfolio) must, after adjustment for cross-holdings, equal asset-weighted aggregations of all investor portfolios. Thus the performance of the market portfolio always equals the gross performance of investors. It provides a useful performance benchmark, presents a distillation of marketplace wisdom ${ }^{4)}$ and is the only portfolio that all investors

\footnotetext{
4) It is a highly risky strategy to bet against the market portfolio without a strong belief that the collective thinking of millions of investors is wrong.
} 
can hold at once. In this study it provides each country at least an equal representation while not skewing results in any particular direction. Table 1 shows the make-up of the benchmark.

In selecting styles for analysis, due to the possible interplay of small-cap/large-cap or winner/loser effects, only styles that belonged clearly to either value or growth categories were included. Hybrid styles were avoided. Ignoring other screens such as size and quality was expected to restrict the investigation to the value-versus-growth issue only.

Table 1: Benchmark coverage snapshot

\begin{tabular}{l|c|c}
\hline Country & $\begin{array}{c}\text { No. of Stocks in } \\
\text { the Study }\end{array}$ & $\begin{array}{c}\text { \% of Total Market } \\
\text { Capitalization }\end{array}$ \\
\hline Indonesia & 37 & 62 \\
\hline Malaysia & 89 & 67 \\
\hline Philippines & 46 & 89 \\
\hline Singapore & 50 & 51 \\
\hline Thailand & 66 & 74 \\
\hline \multicolumn{1}{c|}{ Total } & $\mathbf{2 8 8}$ & $\mathbf{6 2}$ \\
\hline
\end{tabular}

\section{Data collection}

The primary value styles that were considered were PER [Price-Earnings-Ratio] (current), PBR [Price-to-Book-Ratio] (current), PCFR [Price-to-Cash-Flow-Ratio] (current), as well as current Dividend Yield (DY). Current values were calculated using share prices and financial numbers at a common point of observation. The growth style calculated was EPS [Earnings Per Share] growth. Table 2 gives the definitions used in making both value and growth distinctions.

Portfolios for the individual styles were constructed with perfect foresight and (as required by the Mean-VarianceTracking-Error approach) bear-sales were not allowed (Chow, 1995). The database was thus sorted in ascending order for all value styles (except for dividend yield) and in descending order for all growth styles and the top and bottom quintiles were demarcated. Only the top quintile $\left(\mathrm{Q}_{1}\right)$ being the preferred style end and representing companies with low PER, PBR, PCFR, as well as those of companies with high EPS growth and dividend yield were considered. To make the whole exercise as dynamic as possible the style portfolios were rebalanced every month.

\section{Analysis and discussion}

At first, the notion of style overlap may appear difficult to measure. This is especially so when the degree of that overlap has to be related to market movement. However, using multi-dimensional scaling, styles with a greater degree of overlap will fall closer together in multi-dimensional space and those perceived to be dissimilar would be further apart. Cooper and Emory (1995) identify questions of variance as being construct measures rather than those of content or criterion. They suggest that because of the interdependency being posited, multitrait-multimethod analysis that attempts to, both identify the underlying construct being measured and determine how well the test represents it, should be used. This ensures that the measurement has an acceptable degree of validity. Thus, to effectively test the hypothesis, it required two types of attribute space to be introduced. First, the percentage of stocks, on a monthly basis, that were in the top quintile of EPS growth $\left(Q_{1}\right)$, as well as the top quintile of the major value (current) styles were calculated based on the theoretical definitions contained in Table 2. This could then be compared with the movement of the benchmark as a whole.

\section{Table 2: How screen styles were identified}

\begin{tabular}{|c|c|c|c|}
\hline Ratio & Definition Employed & $\begin{array}{c}\text { Value } \\
\text { Characteristic }\end{array}$ & $\begin{array}{c}\text { Growth } \\
\text { Characteristic }\end{array}$ \\
\hline PER & Share price over EPS & $\begin{array}{l}\text { Must have } \\
\text { been less than } \\
40 \% \text { of the } \\
\text { average } \\
\text { market PE }\end{array}$ & $\begin{array}{l}\text { Must have } \\
\text { been more } \\
\text { than } 40 \% \text { of } \\
\text { the average } \\
\text { market PE }\end{array}$ \\
\hline PBR & $\begin{array}{l}\text { Share price over } \\
\text { shareholders equity per } \\
\text { share }\end{array}$ & $\begin{array}{l}\text { Price }<\text { Two- } \\
\text { thirds of book } \\
\text { value }\end{array}$ & $\begin{array}{l}\text { Price }>\text { Two- } \\
\text { thirds of book } \\
\text { value }\end{array}$ \\
\hline PCFR & $\begin{array}{l}\text { Share price over cash } \\
\text { flow per share based on } \\
\text { EPS plus depreciation } \\
\text { and amortisation minus } \\
\text { monetary gain/loss and } \\
\text { foreign exchange } \\
\text { gain/loss per share for the } \\
\text { fiscal year }\end{array}$ & $\begin{array}{l}\text { Must have } \\
\text { been less than } \\
20 \% \text { of the } \\
\text { average } \\
\text { market PCFR }\end{array}$ & $\begin{array}{l}\text { Must have } \\
\text { been more } \\
\text { than } 20 \% \text { of } \\
\text { the average } \\
\text { market PCFR }\end{array}$ \\
\hline $\begin{array}{l}\text { Dividend } \\
\text { Yield } \\
\text { (DY) }\end{array}$ & $\begin{array}{l}\text { Dividend on the main } \\
\text { type of share multiplied } \\
\text { by the grossing up factor, } \\
\text { expressed as a percentage } \\
\text { of the price of the main } \\
\text { type of share }\end{array}$ & $\begin{array}{l}\text { Dividend } \\
\text { Yield greater } \\
\text { than the } \\
\text { average } \\
\text { corporate bond } \\
\text { yield }\end{array}$ & $\begin{array}{l}\text { Dividend } \\
\text { Yield less than } \\
\text { average } \\
\text { corporate bond } \\
\text { yield. }\end{array}$ \\
\hline $\begin{array}{l}\text { EPS } \\
\text { growth }\end{array}$ & $\begin{array}{l}\text { Year-on-year growth in } \\
\text { Earnings per Share }\end{array}$ & $\begin{array}{l}\text { Growth less } \\
\text { than twice } \\
\text { inflation rate }\end{array}$ & $\begin{array}{l}\text { Growth greater } \\
\text { than twice } \\
\text { inflation rate }\end{array}$ \\
\hline
\end{tabular}

Source: Adapted from Arnott and Copeland (1985); Forsythe (1995)

Figures 1 and 2 are spatial maps that suggest similarities in terms of relative distance. They have been smoothed on an annual basis to show style overlap in terms of correspondent span. Figure 1 shows that the overlap between growth and the Price-Earnings Ratio lead the benchmark. This often occurs because price earnings rise sharply in the absence of earnings recovery at the early stages of equity market rerating. Because of the popularity of this measure in the investment community, unit trust investors would do well in scrutinizing the classificatory system used, in relation to market phase, when investing in style portfolios. Figure 1 in particular shows that $\mathrm{DY}_{\mathrm{c}}$ stood out on the whole, for its lower overlap with EPS growth. In other words, a DY strategy is a much purer play on value than $\mathrm{PER}_{\mathrm{c}}$ (or any other value style), which shows a higher level of growth contamination. Dorfman (1996) describes how some investors use dividend yields as a stock-picking strategy for investing in the 30 stocks which make up the Dow Jones Industrial Average. Investors often buy at the beginning of each year the ten Dow industrials with the highest dividend yields. After the year the investor weeds out those not among the highest yielding and buys new high-yielders. 
This strategy has led to annual returns of more than six percentage points above those of the industrial average as a whole ${ }^{5}$. A high dividend yield is often a sign of a depressed stock price. Thus they offer not only a dividend in the hand (when cash carries a premium in a bear market) but also a potential capital gain in the bush (when stocks bounce back in bull runs).

Figure 2 shows the trend in overlap between EPS growth and $\mathrm{PBR}_{\mathrm{c}}$. Overlap with this counter seems to lead the benchmark although in later years it is more subdued. This may be because book values become more important during bear markets when the emphasis moves from the income statement to the balance sheet. The Price to Cash Flow Ratio overlap appears direction independent at first, possibly a result of earnings being highly sensitive to changes in depreciation while cash flows are not. Because there is a substantial increase in overlap before the mature bull phase sets in, this may imply that depreciation charges peak in bear rather than bull markets. Taken together, these diagrams show that a substantial portion of variation in overlap between growth and value appears to be aligned with market movement. Baker (1993) suggests that such overlap may be persistent because value and growth are the primary determinants of stock price in any fundamental approach. The simple constant (Gordon's) growth dividend discount model, for example, expresses a stock in terms of its dividend yield (value) and its growth rate (growth). Since virtually all fundamental models are modifications of this simple case, the value and growth dichotomy will obtain in every one.
This contamination may be beneficial or detrimental depending on the risk-and-return characteristics of individual styles under various market conditions and on investor objectives. For example, an investor in a bear market could opt for either a relatively pure value play using a DY ${ }_{c}$ strategy or for a $\mathrm{PER}_{\mathrm{c}}$ strategy which, by virtue of its greater overlap with EPS growth, offers a hedge (of growth against value). Taken together because overlap rose when the market (represented by the benchmark index) rose and fell when the market fell, the hypothesis could not be rejected. Of course, because multi-dimensional scaling has no statistical solution, confirmation of the hypothesis requires further study.

It follows that the degree of differentiation between growth and value rises as the market declines, and that styles are purer at the bottom than at the top. Thus, investors who feel the need to hedge (between value and growth) must employ more active hedging strategies in bear markets than in bull markets because styles are internally hedged to a certain extent in the latter.

\section{Investment Implications}

Value-growth overlap trends may also have utility as indicators of market direction. Excessively high levels of overlap appear to correlate with market peaks and excessively low levels with market troughs. It may therefore be useful to monitor this variable, from a technical perspective, as a guide to market timing.
Fig. 1: Overlap (Q1) of EPS Growth with PERc and DYc

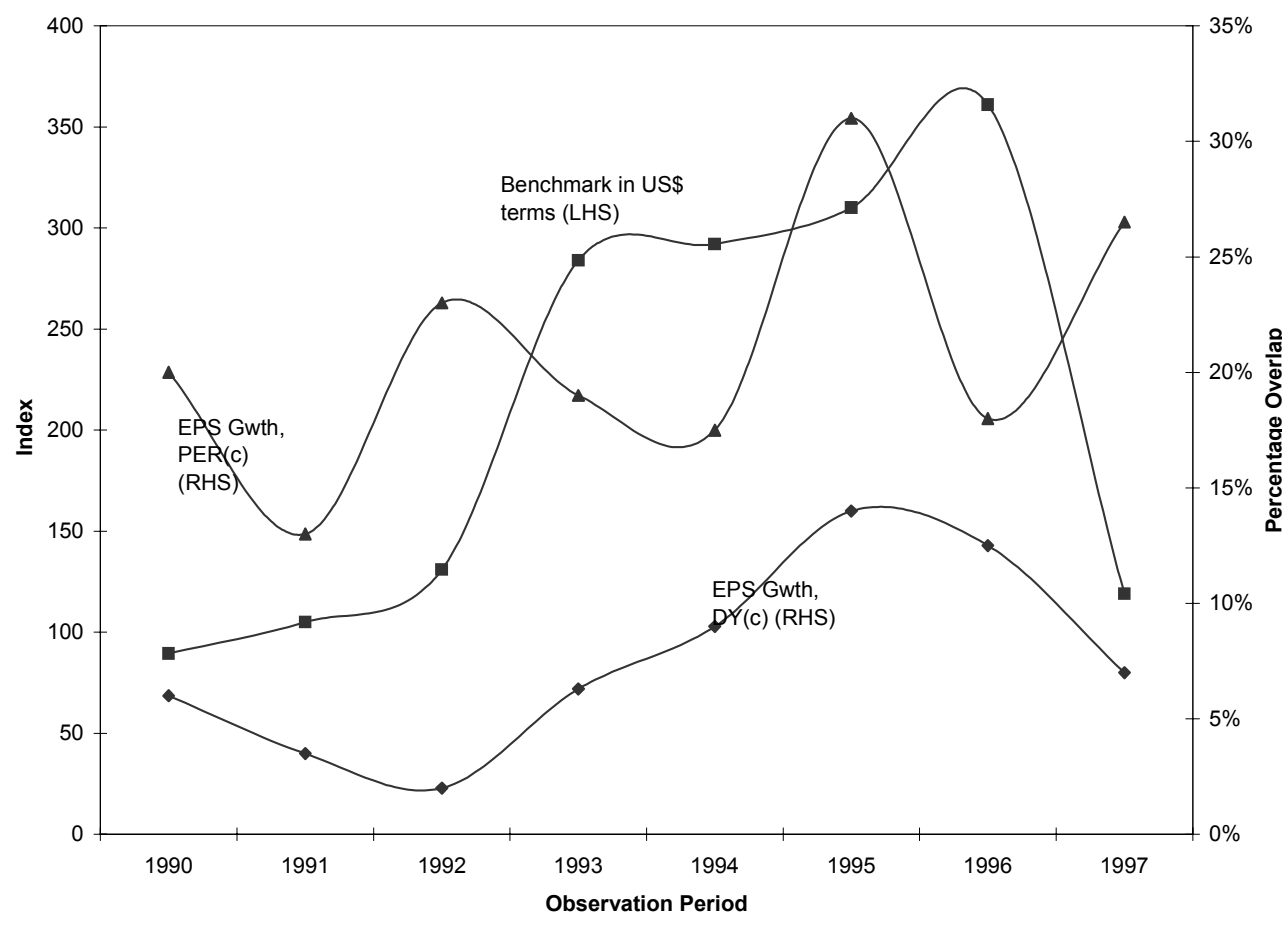

-Benchmark

$\multimap$ EPS/DY

$\leftarrow$ EPS/PERc

${ }^{5}$ Twists on this strategy abound, for instance investing in the five lowest priced stocks among the ten high yielders. 
Fig. 2: Overlap (Q1) of EPS Growth with PBRc and PCFRc

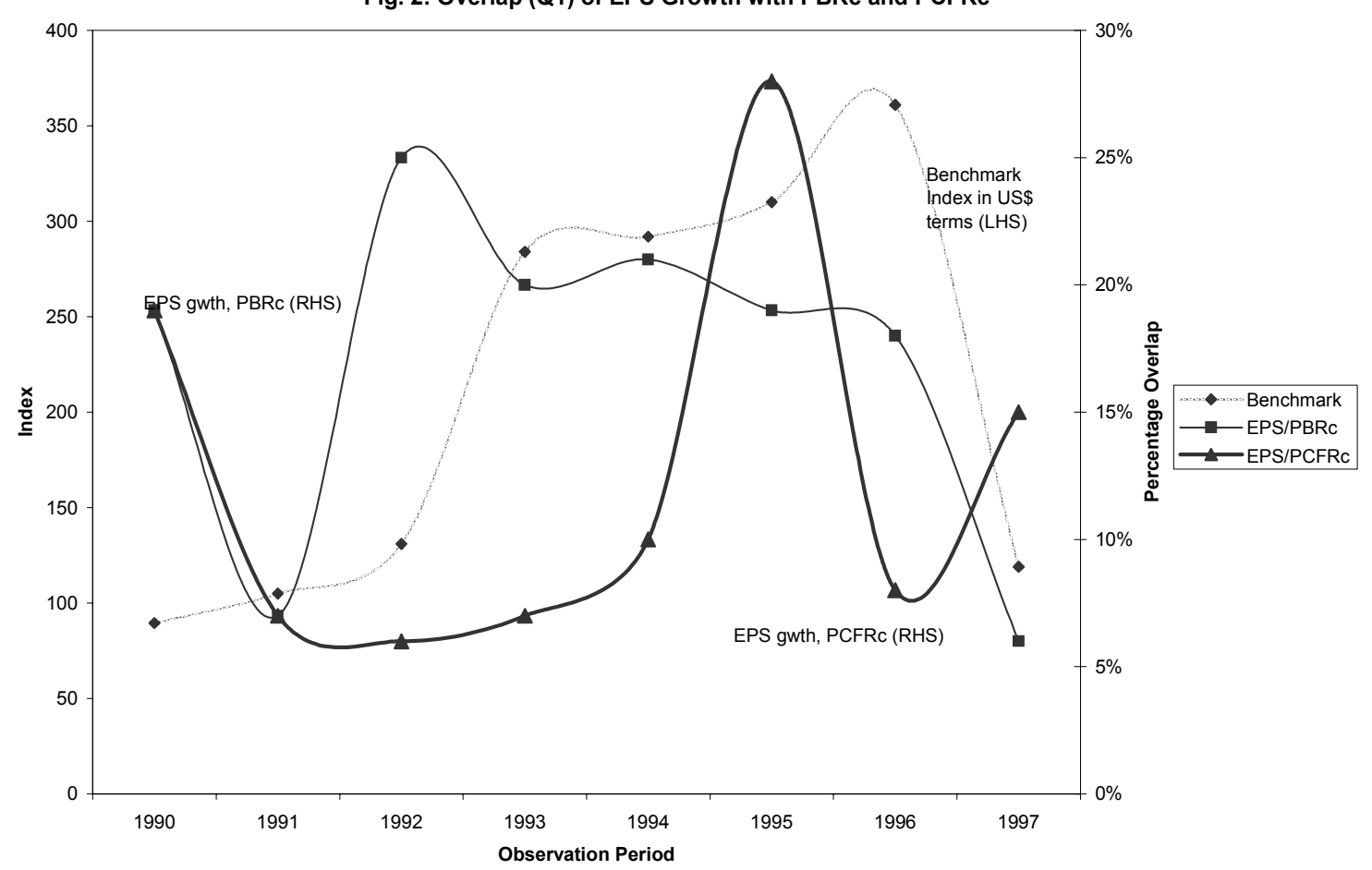

\section{References}

Ankrim, E. 1993. 'The Japanese weighting decision in international Equity portfolios: Measuring the impact', Russell Research Commentary, June. New York: Frank Russell Company.

Ankrim, E. \& Gardner, G. 1994. 'Choosing a non-US equity benchmark: Are there good reasons for under weighting Japan?', Russell Research Commentary, December. New York: Frank Russell Company.

Arnott, R. D. \& Copeland, W. A. 1985. 'The business cycle and security selection', Financial Analysts Journal, 41(2):26-32.

Baker, E. 1993. 'Normal portfolios and manager styles: The money manager's perspective'. In Essinger, J. (Ed.). The investment manager's handbook. London: Chapman and Hall.

Banz, R. W. 1981. 'The relationship between return and market value of common stock', Journal of Financial Economics, 9(1):3-18.

Chan, L. K. C., Hamao, Y. \& Lakonishok, J. 1993. 'Fundamentals and stock returns in Japan', Journal of Finance, 46(5):1739-64.
Chow, G. 1995. 'Portfolio selection based on return, risk and relative performance', Financial Analysts Journal, 51(2):54-60.

Cooper, D. R. \& Emory, C. W. 1995. Business research methods (5th edition). Chicago: Irwin.

Cootner, P. 1964. The random character of stock market prices. Cambridge, Mass.: The MIT Press.

Dorfman, J. R. 1996. 'The power of Dow dividends', The Wall Street Journal, November 11.

Fama, E. F. \& French, K. R. 1992. 'The cross-section of expected stock returns', Journal of Finance, 47(2):427465.

Forsythe, G. J. 1995. 'How does stock selection criteria performance vary across investment style universes?' In Klein, R. A. \& Lederman, J. (Eds.). Equity style management: Evaluating and selecting investment styles. Burr Ridge, Il.: Irwin Professional Publishing.

Gillies, J. 1990. 'Reflecting Gross Domestic Product in an international equity index', Russell Research Commentary, November. New York: Frank Russell Company.

Jegadeesh, N. \& Titman, S. 1993. 'Returns to buying winners and selling losers: Implications for stock market efficiency', Journal of Finance, 48(1):65-91. 
Malkiel, B. G. 1993. 'Returns from investing in equity mutual funds 1971-1991', Working Paper, No.15, Center for Economic Policy Studies: Princeton University.

Price, J. R. Jnr. 1939. 'Picking growth stocks'. Reprinted In Ellis, C.D. (Ed.). 1989. Classics: An investors anthology. Charlottesville, VA.: Institute of Chartered Financial Analysts.

Rosenberg, B., Reid, K. \& Lanstein, R. 1985. 'Persuasive evidence of market inefficiency', Journal of Finance, 11(3):9-17.

Sergio, B. \& Sorensen, E. H. 1992. Segregating growth from value is not always either/or. New York: Salomon Brothers Inc.

Sorensen, E. H. \& Lazzara, C. J. 1995. 'Equity style management: The case of growth and value'. In Klein, R. A. and Lederman, J. (Eds.). Equity style management: Evaluating and selecting investment styles. Burr Ridge, Il.: Irwin Professional Publishing.

Umstead, D. 1990. 'Weighting the options: Market-weight open to one-country domination', Pensions and Investment Age, 13(5):13-29. 